Volume 5 Nomor 1 Oktober 2021

e-ISSN: 2549-9114 dan p-ISSN: 2549-9203

(Received: September-2020; Reviewed: Januari-2021; Published: April-2021)

DOI: https://doi.org/10.26858/pembelajar.v5i1.14975

\title{
Pengaruh Kompetensi Pedagogik Guru Terhadap Keterampilan Intelektual Siswa di Kelas V SD Negeri 1 Trusmi Wetan
}

\author{
Nur'aeni', Fanny Septiany Rahayu' ${ }^{2}$, Aiman Faiz \\ Fakultas Keguruan dan Ilmu Pendidikan, Universitas Muhammadiyah Cirebon, Indonesia \\ Corresponding e-mail: 3aimanfaiz@umc.ac.id
}

\begin{abstract}
Abstrak: Tujuan penelitian ini adalah untuk menjawab adakah pengaruh pedagogik guru dalam mengembangkan keterampilan intelektual siswa. Untuk memperoleh data, penelitian ini menggunakan metode penelitian kuantitaf survey yang dengan fokus penelitian pengaruh kompetensi pedagogik guru terhadap keterampilan intelektual siswa di kelas V SD Negeri 1 Trusmi Wetan. Teknik pengumpulan data menggunakan kuesioner dan studi dokumentasi. Adapun yang menjadi sumber data primer adalah guru SD Negeri 1 Trusmi Wetan dan data sekunder siswa kelas V di SD Negeri 1 Trusmi Wetan. Secara umum, hasil penelitian ini pengaruh kompetensi pedagogik guru pada pembelajaran sangat efektif untuk meningkatkan keterampilan intelektual siswa. Berdasarkan analisis data ditemukan bahwa hasil uji hipotesis data variabel X (kompetensi pedagogik guru) terhadap keterampilan intelektual siswa menunjukan nilai t-hitung sebesar 2,548>t-tabel 1,724 dan besarnya pengaruh kompetensi pedagogik terhadap keterampilan intelektual adalah $=$ 0,012 atau $12 \%$ sehingga dianggap signifikan karena $0,012<0,05$. Dari hasil tersebut dapat diartikan bahwa kompetensi pedagogik berpengaruh secara positif dan signifikan terhadap keterampilan intelektual pada siswa SD Negeri 1 Trusmi Wetan..
\end{abstract}

Kata Kunci: Kompetensi Pedagogik, Ketermpilan Intelektual, Sekolah Dasar

Abstract: The purpose of this study was to answer whether there was any influence of teacher pedagogy in developing students' intellectual skills. To obtain data, this study used a quantitative survey research method that focused on the effect of teacher pedagogical competence on the intellectual skills of students in grade V SD Negeri 1 Trusmi Wetan. Data collection techniques using questionnaires and documentation study. The primary data sources are SD Negeri 1 Trusmi Wetan teachers and secondary data for fifth grade students at SD Negeri 1 Trusmi Wetan. In general, the results of this study the effect of teacher pedagogical competence on learning is very effective in improving students' intellectual skills. Based on the data analysis, it was found that the results of the $\mathrm{X}$ variable data hypothesis test (teacher pedagogical competence) on students' intellectual skills showed a t-count value of $2.548>$ t-table 1.724 and the magnitude of the influence of pedagogic competence on intellectual skills was $=0.012$ or $12 \%$ so it was considered significant because $0.012<0.05$. From these results it can be interpreted that pedagogic competence has a positive and significant effect on intellectual skills of students of SD Negeri 1 Trusmi Wetan.

Keywords: pedagogic competence, intellectual skills, Primary school

(C2021 -Ini adalah artikel dengan akses terbuka dibawah licenci CC BY-NC-4.0

(https://creativecommons.org/licenses/by-nc/4.0/) by penulis. 


\section{PENDAHULUAN}

Pendidikan adalah usaha sadar dan sistematis, yang dilakukan orang-orang yang diserahi tanggung jawab untuk mempengaruhi peserta didik agar mempunyai sifat dan tabiat sesuai dengan cita-cita pendidikan. Dalam arti lain, pendidikan merupakan pendewasaan peserta didik agar dapat mengembangkan bakat, potensi, dan keterampilan yang dimiliki dalam menjalani kehidupan, sudah seharusnya pendidikan didesain guna memberikan pemahaman serta meningkatkan prestasi belajar siswa (Daryanto, 2010: 1). Selain itu, fungsi pendidikan (sekolah) sebagai lembaga pendidikan formal yang mempunyai program yang sistemik dalam melaksanakan bimbingan, pengajaran dan latihan kepada anak (siswa) agar mereka berkembang sesuai potensinya (Yusuf dalam Aiman 2019: 3).

Tentunya penggerak pendidikan yaitu seorang guru perlu memiliki kepribadian, menguasai bahan pelajaran dan menguasai caracara mengajar sebagai kompetensinya. Tanpa hal tersebut guru akan gagal dalam melaksanakan tugasnya. Jadi kompetensi mengajar harus dimilki oleh seorang guru yang merupakan keterampilan dalam mengelola kegiatan pendidikan. Disamping hal tersebut di atas, "Kompetensi dalam proses interaksi belajar mengajar dapat pula menjadi alat motivasi ekstrinsik, guna memberikan dorongan dari luar diri siswa" (Djamarah, 2002: 17).

Kemampuan pengelolaan pembelajaran atau kompetensi pedagogik harus dimiliki oleh semua guru, atau calon guru dalam mengemban tugasnya agar proses belajar mengajar dapat dilaksanakan secara efektif dan efisien serta hasil yang dicapai sesuai dengan harapan. Standar Nasional Pendidikan, penjelasan Pasal 28 ayat (3) butir a dikemukakan bahwa kompetensi pedagogik adalah kemampuan mengelola pembelajaran peserta didik yang meliputi pemahaman terhadap peserta didik, perancangan dan pelaksanaan pembelajaran, evaluasi prestasi belajar, dan pengembangan peserta didik untuk mengaktualisasikan berbagai potensi yang dimilikinya (Peraturan Pemerintah Republik Indonesia No. 19 tentang Standar Nasional Pendidikan, 2005:27).

Aspek intelektual anak SD merupakan salah satu aspek psikologis yang sangat perlu di pahami dan dihayati oleh seorang pendidik. Pemahaman dan penghayatan ini dipandang penting sebab hakikatnya pembelajaran yang diselenggarakan pendidik harus disesuaikan dengan tingkat perkembangan intelektual anak.
Bahkan dalam pandangan Piaget, pembelajaran yang tidak sesuai dengan perkembangan intelektual anak memiliki konsekuensi negatif bagi perkembangan aspek psikologis lainnya.

Keterampilan intelektual merupakan ekspresi dari intelgensi. Inteligensi memiliki makna sama dengan kecerdasan. Mengasah kemampuan dasarsiswa selaku peserta didik sangat penting untuk menunjang proses pembelajaran agar tujuan pendidikan dapat tercapai. Keterampilan intelektual dasar anak yang harus dikembangkan erat kaitannya dengan kecerdasan yang dimiliki anak (Hastuti, U. R., 2019: 42). Pada siswa tingkat sekolah dasar merupakan usia emas bagi anak untuk mengembangkan potensi kecerdasan intelektual. Keterampilan dasar yang diajarkan pada siswa SD ialah membaca dan berbicara. (Yumnah, 2016: 31).

Sejalan dengan perubahan tersebut, kompetensi pedagogik guru yakni pengelolaan kelas yang dapat melibatkan siswa secara aktif berpikir. Pembelajaran yang mengutamakan penguasaan kompetensi harus berpusat pada siswa (focus on learners). Pembelajaran yang dapat memberikan pengalaman belajar yang relevan dan kontekstual dalam kehidupan nyata dan mengembangkan mental yang kaya dan kuat pada siswa. Guru perlu mencari strategi atau model yang cocok untuk topik yang akan diajarkan sehingga pengetahuan dapat tersampaikan secara sistematis dan menyenangkan.

Guru merupakan komponen paling berpengaruh terhadap terciptanya proses dan hasil pendidikan yang berkualitas. Upaya perbaikan apapun yang dilakukan untuk meningkatkan kualitas pendidikan tidak akan memberikan sumbangan yang signifikan tanpa didukung oleh guru yang profesional dan berkualitas. Dengan kata lain, perbaikan kualitas pendidikan harus berpangkal dari guru dan berujung pada guru pula.

Kecerdasan intelektual dibangun melalui berbagai faktor, diantaranya keturunan genetik dan proses pembelajaran. Kecerdasan yang diperoleh melalui keturunan genetik tetap harus dikembangkan dan diasah melalui proses pendidikan dan pembelajaran baik secara formal maupun informal. Secara efesien pembentukan kecerdasan intelektual dibangun sejak dini agar dapat berkembang secara optimal seiring tumbuh kembangnya seorang individu (Isnaniah, 2020: 1).

Berdasarkan hal tersebut, maka setiap guru dituntut untuk mempunyai kompetensi. Kompetensi adalah kecakapan seseorang dalam bidang yang dijalaninya. Kompetensi pedagogik merupakan kemampuan seseorang dalam 
mengelola pembelajaran peserta didik yang meliputi pemahaman terhadap peserta didik, perancangan dan pelaksanaan pembelajaran, evaluasi hasil belajar, dan pengembangan peserta didik untuk mengaktualisasikan potensi yang dimiliki peserta didik.

\section{METODE}

Metode penelitian yang digunakan dalam penelitian ini digunakan metode survey dengan deskriptif analisis. desain yang digunakan dalam penelitian yang penulis lakukan adalah analisis regresi, untuk mengetahui tingkat pengaruh antara variabel yang sama terhadap variabel lainnya.

Untuk melaksanakan hal tersebut peneliti terlebih dahulu melakukan penyebaran kuesioner (angket) tiap-tiap variabel penelitian kepada responden. Setelah data yang diperlukan terkumpul, dilakukan langkah-langkah analisa data dan pengujian hipotesis melalui pendekatan statistik parametrik. Dalam penelitian ini yang dianalisis adalah Pengaruh Kompetensi Pedagogik Guru terhadap Keterampilan Intelektual Siswa di Kelas V SD Negeri 1 Trusmi Wetan.

Teknik pengambilan sampel dalam penelitian ini mengacu kepada teori yang dikemukakan oleh Arikunto(2010:104) yang menyatakan bahwa apabila subyek kurang dari 100, maka lebih baik diambil seluruhnya, tetapi apabila jumlah subyek lebih dari 100 dapat diambil antara $10-15 \%$ atau $20-25 \%$ atau lebih. Karena populasi dalam penelitian ini lebih dari 100 (189), maka sampel yang digunakan dalam penelitian ini adalah sebanyak $16 \%$ dari 189 populasi penelitian atau hanya mengambil 31 responden dari keseluruhan populasi penelitian, teknik pengambilan sampel yang digunakan adalah dengan cara mengambil 31 Siswa Kelas V SD Negeri 1 Trusmi Wetan.

Metode pengumpulan data dalam penelitian ini dilakukan dengan tata cara sebagaimana berikut:

1. Wawancara

Wawancara digunakan oleh penulis dalam rangka observasi awal penelitian yang tujuannya untuk mengumpulkan data-data penelitian awal seperti menemukan masalah penelitian, kondisi objek penelitian yang akan diteliti. Dalam penelitian ini wawancara dilakukan peneliti pada Guru di kelas V SD Negeri 1 Trusmi Wetan.

\section{Kuesinoer (Angket)}

Kuesioner atau angket digunakan oleh peneliti dalam rangka pengumpulan data pokok, yaitu memperoleh data seputar Pengaruh
Kompetensi Pedagogik Guru Terhadap Keterampilan Intelektual Siswa Kelas V SD Negeri 1 Trusmi Wetan. Kuesioner merupakan teknik pengumpulan data yang dilakukan dengan cara memberi seperangkat pertanyaan atau pertanyaan tertulis kepada responden untuk dijawabnya (Sugiyono, 2012:199).

Angket (kuesioner) ini digunakan untuk mengetahui tanggapan siswa yang menjadi subjek penelitian tentang kompetensi pedagogic guru yang diterapkan.

\section{Studi Dokumentasi}

Studi dokumentasi dalam penelitian ini adalah metode yang digunakan peneliti untuk mendokumentasikan data-data yang berkaitan dengan penelitian, seperti kondisi objek penelitian, dan referensi yang diperlukan dalam penyusunan laporan penelitian yang bersumber dari buku-buku, jurnal yang berkaitan dengan penelitian, seperti buku-buku manajemen ekonomi yang membahas mengenai kompetensi pedagogic guru, keterampilan intelektual siswa, maupun buku-buku yang membahas tentang statsitika.

Teknik analis data yang digunakan dalam penelitian ini adalah menyangkut teknik analisis data yang melibatkan kuesioner atau angket sebagai hasil penelitian yang pokok serta menganalisis nilai pengaruh variabel independen $(\mathrm{X})$ terhadap variabel dependen (Y), teknik analisis yang digunakan dalam penelitian ini menggunakan rumus-rumus analisis sebagai berikut:

1. Uji Instrumen Penelitian

Uji instrument penelitian dalam pembuatan karya ilmiah ini adalah sebagai berikut:

a. Uji Validitas

Analisa yang digunakan dalam uji validitas dalam penelitian ini adalah dengan menggunakan korelasi produk moment sesuai dengan pendapat pearson. Rumus uji validitas dalam penelitian ini berlaku untuk instrumen penelitian angket variabel $\mathrm{X}$ dan $\mathrm{Y}$, agar nantinya dalam melakukan perhitungan dapat lebih efesien dan cepat maka penulis menggunakan program SPSS (Statistical product and Service solution) 16.

b. Uji Reliabilitas

Uji reliabilitas dilakukan untuk mengetahui sejauh mana hasil suatu pengukuran dapat dipercaya. Dalam penelitian ini, penulis menggunakan program SPSS (Statistical product and Service solution) 16, dengan pendekatan Cronbach's Alpha.

2. Uji Asumsi Klasik 
Asumsi klasik yang akan diuji dalam penelitian ini adalah sebagai berikut:

a. Uji Normalitas

Uji normalitas data pada penelitian ini menggunakan bantuan komputasi aplikasi SPSS 17 dengan langkah-langkah sebagai berikut :

1) Input data

2) Klik Analyze

3) Klik Npara Test

4) Masukan data pada kolom tersedia

5) Centang Normal

6) Klik Ok

b. Uji Linearitas

Uji linearitas digunakan untuk mengetahui apakah variabel bebas dan terikat dalam penelitian ini memiliki hubungan yang linear. Dikatakan linear jika kenaikan skor variabel bebas diikuti kenaikan variabel terikat. Uji linearitas data data pada penelitian ini menggunakan bantuan aplikasi SPSS 17 dengan langkah-langkah sebagai berikut :

1) Input data

2) Klik Analyze

3) lik Compare Mean

4) Masukan data pada kolom tersedia

5) Centang Test for Linearity

6) Klik Ok

3. Uji Regresi

masalah yag dibahas dalam penelitian ini adalah apakah Kompetensi Pedagogik Guru (X) berpengaruh terhadap Keterampilan Intelektual Siswa (Y), untuk menganalisis masalah penelitian tersebut digunakan metode regresi.

4. Koefisien Determinasi

Koefisien determinasi digunakan untuk mengetahui persentase perubahan variabel dependen yang disebabkan oleh variabel bebas. Semakin besar R2 maka persentase perubahan variabel dependen yang disebabkan oleh variabel independen akan semakin tinggi. Sedangkan apabila R2 semakin kecil, maka persentase perubahan variabel dependen yang disebabkan oleh variabel independen akan semakin rendah 5. Uji Hipotesis

Uji hipotesis disebut juga "konfirmasi analisa data". Keputusan dari uji hipotesis hampir selalu dibuat berdasarkan pengujian hipotesis nol. Ini adalah pengujian untuk menjawab pertanyaan yang mengasumsikan hipotesis nol adalah benar.

\section{HASIL DAN PEMBAHASAN}

Untuk mendapatkan data mengenai kompetensi pedagogik guru, peneliti menggunakan angket langsung, yaitu angket dijawab oleh responden yang telah ditentukan oleh peneliti. Dalam penelitian ini yang dijadikan objek adalah guru di SD Negeri 1 Trusmi Wetan. Dapat diketahui bahwa responden siswa kelas $\mathrm{V}$ SD Negeri 1 Trusmi Wetan dalam penelitian ini yang berjenis kelamin laki-laki sebanyak $62 \%$ dan perempuan sebanyak $38 \%$. Dengan demikian dapat disimpulkan bahwa responden laki-laki lebih banyak daripada responden perempuan.

Setelah pengisian angket dilakukan data kemudian disajikan secara terperinci dari masingmasing indikator yang telah ditetapkan. Data kemudian ditabulasikan dan selanjutnya dilakukan analisis baik secara deskriptif maupun secara statistik guna mencari kesimpulan tentang subjek dan objek penelitian. Sehingga mendapatkan rekapitulasi distribusi frekuensi Kompetensi Pedagogik, dapat diketahui mengenai tanggapan responden terhadap variabel Kompetensi Pedagogik (X). Dari hasil tersebut memperlihatkan indeks rata-rata sebesar 3,77. Dengan demikian rata-rata skor intervalnya berada diantara 3,40 4,19, sehingga dapat diartikan bahwa pemahaman tentang Kompetensi Pedagogik pada guru SD Negeri 1 Trusmi Wetan tergolong tinggi. Hal ini menunjukkan bahwa sebagian besar guru SD Negeri 1 Trusmi Wetan telah mempraktikkan dengan baik seluruh kompetensi pedagogik yang harus dimiliki oleh seorang guru.

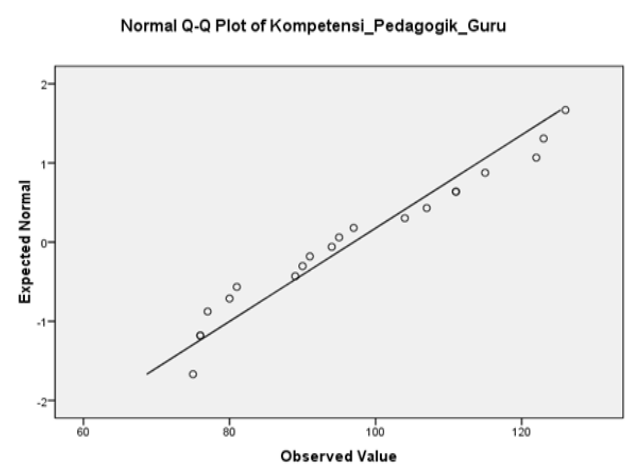

\section{Gambar Grafik 1 \\ Normalitas Data Variabel X Kompetensi Pedagogik Guru}

Sumber : Hasil output program SPSS 16

Untuk mendapatkan data mengenai keterampilan intelektual siswa, peneliti menggunakan angket langsung, yaitu angket dijawab oleh responden yang telah ditentukan oleh peneliti. Dalam penelitian ini yang dijadikan objek adalah siswa-siswi SD Negeri 1 Trusmi Wetan, yaitu kelas $\mathrm{V}$ dengan jumlah 26 siswa. 
Melalui angket yang diisi oleh siswa, sebanyak 195 jawaban "Ya" untuk setiap item pertanyaan, hal ini menunjukkan siswa telah mampu mengetahui, menjelaskan, menganalisis dan mengutarakan solusi atas suatu permasalahan yang terjadi dalam belajar maupun lingkungan sekitar.

Rekapitulasi distribusi frekuensi Keterampilan Intelektual dapat diketahui bahwa tanggapan responden terhadap variabel Keterampilan Intelektual Siswa (Y) memperlihatkan indeks presentase sebesar $75 \%$. Sehingga dapat diartikan bahwa Keterampilan Intelektual Siswa tergolong cukup tinggi. Hal ini menunjukkan bahwa dengan berbekal kompetensi pedagogik guru yang telah diterapkan di kelas serta dengan motivasi untuk belajar membuat responden memiliki semangat belajar yang tinggi dan tercapainya tujuan pendidikan.

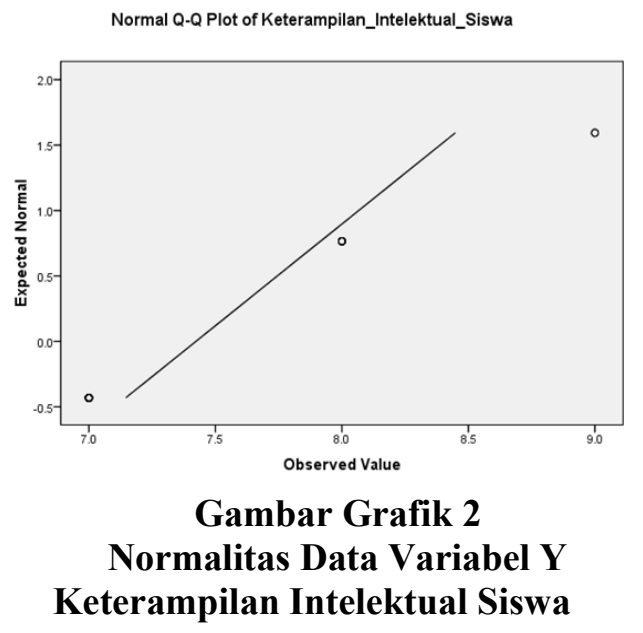

\section{Sumber : Hasil output program SPSS 16}

Pada hasil uji validitas menunjukkan bahwa semua butir pernyataan angket mulai dari butir pernyataan angket nomor 1 hingga butir nomor 30, seluruh harga thitung ternyata lebih besar daripada harga rhitung sehingga seluruhnya dapat dinyatakan valid. Dari hasil perbandingan diatas, dapat disimpulkan bahwa data yang diperoleh dari sebaran angket variabel kompetensi pedagogik guru pada penelitian ini dinyatakan layak dan dianggap valid untuk dilakukan analisis berikutnya.

Selanjutnya setelah data terkumpul dilakukan uji Reliabelitas diperoleh nilai Croncbach Alpha $0.899>0,600$ Sehingga seluruh data variabel X (kompetensi pedagogik guru) adalah reliabel atau dengan kata lain menjaring data variabel $\mathrm{X}$ (kompetensi pedagogik guru) dapat dipercaya / reliable sebagai alat pengumpul data sehingga layak digunakan sebagai bahan analisis berikutnya.Selanjutnya pada uji distribusi frekuensi untuk mementukan kecenderungan responden menjawab pernyataan angket yang diajukan adapun hasil uji distribusi menunjukkan bahwa rata-rata total skor variabel X (kompetensi pedagogik guru) menunjuk pada nilai rata-rata skor sebesar 3,77 jika dikonsultasikan pada tabel rentang nilai dan criteria rata-rata skor berada pada rentang 3,40 - 4,19 tergolong pada kriteria setuju dengan demikian maka secara umum dapat disimpulkan bahwa sebagian besar guru menyatakan setuju dengan adanya penerapan kompetensi pedagogik guru di SD Negeri 1 Trusmi Wetan.

Menurut Center for Civic Education (1994). National Standard for Civic and Goverment, keterampilan intelektual terdiri dari beberapa indikator yang dijabarkan sebagai berikut: mengidentifikasi, menggambarkan, menjelaskan, menganalisis, mengevaluasi, mengambil pendapat, dan memepertahankan pendapat.

Indikator di atas berfungsi untuk menyusun angket yang digunakan untuk menghasilkan data dengan menggunakan analisis sistematik. Sebelum digunakan angket telah melampaui uji validitas dan uji reabilitas. Pada hasil uji validitas menunjukkan bahwa semua butir pernyataan angket mulai dari butir pernyataan angket nomor 1 hingga butir 10, melalui perhitungan formula koefisien reprodusibilitas untuk mengukur angket dengan skala guttman bahwa memiliki nilai 0.962924 dan formula koefisien skalabilitas dengan nilai 0.9762 , sehingga berdasarkan kategori koefisien validitas (Guilford, 1956: 145) bahwa kuesioner dapat disimpulkan baik untuk digunakan dalam survey. Memperhatikan hasil perbandingan diatas dapat disimpulkan bahwa data yang diperoleh dari sebaran angket variabel $\mathrm{Y}$ (keterampilan intelektual) pada penelitian ini dinyatakan layak dan dianggap valid untuk dilakukan analisis berikutnya.

Selanjutnya setelah data terkumpul dilakukan uji reabilitas diperoleh nilai Croncbach Alpha $0.570>$ 0,400 Sehingga seluruh data variabel $\mathrm{Y}$ (keterampilan intelektual) adalah reliabel atau dengan kata lain menjaring data variabel $\mathrm{Y}$ (keterampilan intelektual) dapat dipercaya / reliable sebagai alat pengumpul data sehingga layak digunakan sebagai bahan analisis berikutnya.

Berdasarkan hasil uji hipotesis data variabel $\mathrm{X}$ (kompetensi pedagogik guru) terhadap keterampilan intelektual siswa menunjukan nilai t- 
hitung sebesar 2,548> t-tabel 1,724 dan besarnya pengaruh kompetensi pedagogik terhadap keterampilan intelektual adalah $=0,012$ atau $12 \%$ sehingga dianggap signifikan karena $0,012<0,05$. Dari hasil tersebut dapat diartikan bahwa kompetensi pedagogik berpengaruh secara positif dan signifikan terhadap keterampilan intelektual pada siswa SD Negeri 1 Trusmi Wetan.

Pada hasil uji koefisien determinasi $\mathrm{X}$ (kompetensi pedagogik guru) terhadap variabel Y (keterampilan intelektual siswa) diperoleh nilai koefisien ("r") korelasi sebesar 0,422. Nilai koefisien (" $r$ ") korelasi sebesar 0.422 koefisien ( $\mathrm{r}$ square) menunjukkan bahwa adanya korelasi kedua variable pada katagori korelasi sangat tinggi Besarnya R Square adalah 0,422 atau sama dengan $42,2 \%$. Artinya adalah terdapat pengaruh yang cukup kuat dari variabel kompetensi pedagogik (X) terhadap keterampilan intelektual (Y) pada siswa SD Negeri 1 Trusmi Wetan yaitu sebesar 42,2\% sedangkan sisanya di pengaruhi oleh faktor lain.

\section{KESIMPULAN}

Berdasarkan analisis deskriptif dapat diketahui bahwa tanggapan responden terhadap variabel kompetensi pedagogik memperlihatkan indeks rata-rata sebesar 3,77 Dengan demikian rata-rata skor intervalnya berada diantara Dengan demikian rata-rata skor intervalnya berada diantara 3,40-4,19. Sehingga dapat diartikan bahwa pemahaman tentang kompetensi pedagogik guru SD Negeri 1 Trusmi Wetan tergolong tinggi.

Rekapitulasi distribusi frekuensi Keterampilan Intelektual dapat diketahui bahwa tanggapan responden terhadap variabel Keterampilan Intelektual Siswa (Y) memperlihatkan indeks presentase sebesar $75 \%$. Sehingga dapat diartikan bahwa Keterampilan Intelektual Siswa tergolong cukup tinggi. Hal ini menunjukkan bahwa dengan berbekal kompetensi pedagogik guru yang telah diterapkan di kelas serta dengan motivasi untuk belajar membuat responden memiliki semangat belajar yang tinggi dan tercapainya tujuan pendidikan.

Berdasarkan hasil Uji T diperoleh nilai t-hitung sebesar 2,548> t-tabel 1,724. Sehingga H0 ditolak dan H1 diterima. Dan besarnya pengaruh kompetensi pedagogik guru terhadap keterampilan intelektual siswa adalah $=0,012$ atau $12 \%$ sehingga dianggap signifikan karena $0,012<0,05$. Dari hasil tersebut dapat diartikan bahwa kompetensi pedagogik guru berpengaruh secara positif dan signifikan terhadap keterampilan intelektual pada siswa SD Negeri 1 Trusmi Wetan.

\section{DAFTAR PUSTAKA}

Alfianti, Windhi. (2017). Pengaruh Kompetensi Pedagogik Guru Terhadap Hasil Belajar Siswa Kelas V SDN 2 Nologaten Ponorogo Tahun Pelajaran 2016/2017. IAIN Ponorogo.Skripsi.Tidak diterbitkan. Tersedia: [Online] http://etheses.iainponorogo.ac.id (20 Mei 2020).

Arikunto, S. (2010). Prosedur Penelitian: Suatu Pendekatan Praktik (Edisi Revisi).Jakarta: Rineka Cipta.

Cholilurohman, Abdul Fatah. (2014). Korelasi Antara Tingkat Kecerdasan Intelegensi (IQ) Dengan Tingkat Kecerdasan Spiritual (SQ) Siswa Di MA NU Nurul Huda Semarang Tahun Ajaran 2013/2014. IAIN Walisongo Semarang.Skripsi.Tidak diterbitkan. Tersedia: [Online] http://eprints.walisongo.ac.id (30 Mei 2020).

Daryanto. (2010). Media Pembelajaran. Yogyakarta: Gava Media.

Desmita. (2010). Psikologi Perkembangan .Bandung: PT. Remaja Rosdakarya.

Djamarah, Syaiful Bahri. (2002). Psikologi Belajar. Jakarta: Rineka Cipta.

Faiz, A. (2019). Program Pembiasaan Berbasis Pendidikan Karakter Di Sekolah. Jurnal PGSD Volume 5 (2) Juli-Desember 2019. ISSN: 2088-8295 E-ISSN:2685-9742 Dapat diakses pada : https://ejournal.umc.ac.id/index.php/JPS

Ghozali, Imam. (2013). Aplikasi Analisis Multivariate dengan Program IBM SPSS. Semarang: Penerbit Universitas Diponegoro.

Hadian, Vini Agustiani. (2009). Penerapan Metode Pemecahan Masalah Untuk Meningkatkan Keterampilan Kewarganegaraan Siswa. Universitas Pendidikan Indonesia. Laporan Penelitian. Tidak Diterbitkan. Tersedia: [Online] http://eprints.uny.ac.id (20 Mei 2020).

Hastuti, Ulfah Rulli. (2019). Mengasah Kemampuan Intelektual Melalui Literasi 
Nur'aeni, Fanny Septiany Rahayu, Aiman Faiz. Pengaruh Kompetensi Pedagogik Guru Terhadap Keterampilan Intelektual Siswa

Informasi Model Big 6TM : Integrasi dengan Pembelajaran Model Berpikir Induktif.Jurnal Perpustakaan. Perpustakaan IAIN Purwokerto. Tersedia: [Online] http://journal.uii.ac.id (30 Mei 2020).

Isnaniah. (2020). Membangun Keterampilan Bahasa Sebagai Potensi Utama Kecerdasan Intelektual Bagi Siswa Kelas Rendah. Jurnal Bahasa, Sastra dan Pengajarannya.UPTD SD Negeri 1 Liang Anggang. Tersedia: [online] http://jurnal.stkipbjm.ac.id (30 Mei 2020).

Mahmud. (2010). Psikologi Pendidikan. Bandung: CV. Pustaka Setia.

Murni, Wahid, dkk. (2010). Keterampilan Dasar mengajar. Yogjakarta: Ar-Ruzz Media

Peraturan Pemerintah Republik Indonesia No. 19 Tahun 2005 tentang Standar Nasional Pendidikan (http: google.com. Diakses 31 Mei 2020)

Riduwan. (2010). Dasar-dasar Statistika. Bandung: Alfabeta.

Sadulloh, dkk. (2018). Pedagogik (Ilmu Mendidik). Bandung: Alfabeta.

Singarimbun, Masri. (2009). Metode Penelitian Survei. Jakarta: Pustaka LP3ES Indonesia.

Sugiyono. (2009). Metode Penelitian Kuantitatif, Kualitatif dan $R \& D$. Bandung: Alfabeta.

Sugiyono. (2012). Metode Penelitian Kombinasi. Bandung : Alfabeta.

Surakhmad, Winarno.(2005). Pengantar Penelitian Ilmiah Dasar, Metode dan Teknik. Bandung: Tarsito.

Usman, Moh Uzer. (2016). Menjadi Guru Profesional. Bandung: Remaja Rosdakarya.

Yasin, A. Fatah. (2008). Dimensi-Dimensi Pendidikan Islam. Malang: UIN Malang Press 
PEMBELAJAR: Jurnal Ilmu Pendidikan, Keguruan, dan Pembelajaran. 5 (1) April 2021 